\title{
Peningkatan Pemberian ASI dan MP-ASI Melalui Kader Parapam di Desa Karanganyar, Karanganyar Kebumen
}

\author{
Nurlaila $^{1}$, Eka Riyanti $^{2}$ \\ STIKES Muhammadiyah Gombong \\ 1email: ners_ela@yahoo.co.id
}

\begin{abstract}
ABSTRAK
Latar Belakang. Pertumbuhan dan perkembangan anak sesuai tahap dipengaruhi oleh asupan gizi yang baik. Status gizi anak dipengaruhi oleh asupan nutrisi saat kehamilan, pemberian ASI Eksklusif dan pemberian MP ASI yang baik. Keberhasilan dalam menyusui dan pemberian MP-ASI dapat didukung oleh pengetahuan ibu yang baik serta peran serta kader kesehatan. Kader kesehatan dapat memberikan informasi serta mendampingi ibu dalam proses menyusui dan pemberian makan. Tujuan kegiatan ini adalah pembentukan kader PARAPAM (Para Pendamping ASI dan MP-ASI) untuk meningkatkan pemberian ASI Eksklusif dan MP-ASI pada bayi di Desa Karanganyar, Karanganyar, Kebumen. Metode yang digunakan adalah ceramah, diskusi, dan demonstrasi. Materi yang diberikan meliputi pendidikan kesehatan, ASI Eksklusif dan MP-ASI. Jumlah kader yang dilatih 31 orang, Kader dilatih melakukan pendidikan kesehatan kepada masyarakat dan melakukan pendampingan saat menyusui dan pemberian MP-ASI. Media yang digunakan berupa power point, lembar balik, leaflet serta booklet Pemberian ASI dan MP-ASI. Hasil penilaian kegiatan ini menunjukan bahwa kader PARAPAM mampu memberikan edukasi kepada ibu hamil dan menyusui serta mampu membantu ibu dalam pemberian ASI Eksklusif dan MP-ASI. Hasil observasi penulis pada bulan ketiga menunjukan bahwa Ibu yang memiliki bayi usia 6 bulan dapat memberikan ASI eksklusif dan ibu yang memiliki bayi usia lebih dari 6 bulan dapat menyiapkan MP-ASI dengan baik.
\end{abstract}

Kata Kunci: Kader, ASI, PARAPAM, MP-ASI

\begin{abstract}
Growth and development of children according to stage, influenced by good nutritional intake. The nutritional status of children is influenced by nutritional intake during pregnancy, exclusive breastfeeding and the provision of good breast milk complement. Success in breastfeeding and giving breast milk complement can be supported by good mother's knowledge and health cadres' role. Health cadres can provide information and assist mothers in the process of breastfeeding and food.The purpose of this activity is the formation of PARAPAM cadres (Assistance for breastfeeding and it's complement) to increase exclusive breastfeeding and breast milk complement in infants in Karanganyar Village, Karanganyar, Kebumen. The method used is lecture, discussion, and demonstration. The material provided include health education, exclusive breastfeeding and breast milk complement. The number of trained cadres are 31 people, cadres were trained to do health education to the community and provide assistance while breastfeeding and giving it's complement. The media used in the form of power points, flipcharts, leaflets and booklets for breastfeeding and it's complement. The result of the assessment of this activity showed that PARAPAM cadres were able to provide education to pregnant and lactating mothers and were able to assist mothers in giving exclusive breastfeeding and it's complement. The author's observation results in the third month show that mothers who have babies age of 6 months can provide exclusive breastfeeding while mothers who have babies over the age of 6 months can prepare breast milk complement properly.
\end{abstract}

Keywords: Cadre, ASI, PARAPAM, MP-ASI 


\section{PENDAHULUAN}

Gizi berperan penting dalam proses pertumbuhan dan perkembangan anak. Status gizi anak dipengaruhi oleh asupan gizi yang didapat ibu saat hamil maupun sesudah bayi lahir. Secara nasional, prevalensi pada tahun 2018 gizi buruk adalah 3,9\% dan gizi kurang sebesar 13,8 \%. Kondisi ini belum mencapai target RPJMN 2019 yaitu sebesar 17\%. Sedangkan prevalensi status gizi pendek meningkat pada tahun 2013 yaitu sebesar 19,2\% dibandingkan dengan tahun 2007 sebesar 18,0\%. Hal ini menunjukan bahwa masalah gizi masih merupakan masalah kesehatan masyarakat (Riskesdas, 2018).

Status gizi balita juga dipengaruhi oleh praktik pemberian ASI Eksklusif. Berdasarkan SDKI tahun 2012 sebanyak $41 \%$ bayi usia 0-6 bulan mendapatkan ASI eksklusif dan sebanyak $55 \%$ melanjutkan menyusui sampai usia 24 bulan. Hal ini menunjukan masih kurangnya cakupan pemberian ASI eksklusif di Indonesia. Sedangkan berdasarkan profil kesehatan Indonesia 2014 menunjukan bahwa cakupan ASI Eksklusif di jawa tengah 60\%. Keberhasilan pemberian ASI eksklusif dapat didukung oleh adanya edukasi bagi ibu hamil dan menyusui serta praktik Inisiasi Menyusui Dini (IMD) (Kementerian Kesehatan Republik Indonesia, 2013). Sedangkan berdasarkan Riskesdas 2013 menunjukkan bahwa 19,7 \% ibu menyusui tidak mendapatkan edukasi 34, 5\% dan praktik IMD dalam waktu kurang dari 1 jam setelah lahir di sebesar jawa tengah 37,5\%. Hal ini menunjukan perlu adanya pemberian pendidikan kesehatan mengenai ASI eksklusif (Kementrian Kesehatan Badan Penelitian dan Pengembangan Kesehatan, 2018).

ASI eksklusif merupakan pemberian nutrisi paling baik pada bayi sejak kelahiran hingga 6 bulan tanpa diberikan makanan pendamping seperti bubur maupun susu formula. ASI sangat bermanfaat untuk bayi selain sebagai sumber tenaga bagi bayi, ASI juga dapat meringankan pencernaan, meningkatkan kekebalan tubuh, dapat mengurangi resiko angka kurang gizi serta gizi buruk pada bayi dan dapat mengurangi resiko obesitas (kegemukan). Selain dapat bermanfaat bagi bayi sang ibu juga diuntungkan dari segi ekonomi karena tidak perlu untuk membeli susu formula, tahan lama basi, dan praktis, mengurangi berat badan sang ibu dan mengurangi resiko kanker payudara (Nurlaila, Utami, \& Cahyani, 2018).

Pemberian MP-ASI juga berperan dalam pertumbuhan dan perkembangan bayi pada usia setelah 6 bulan. Beberapa penelitian menyebutkan bahwa masalah gizi pada bayi dan anak disebabkan kebiasaan ASI dan MP-ASI yang tidak tepat (kuantitas dan kualitas). Selain itu, adanya kebiasaan pemberian makanan bayi yang tidak tepat seperti: pemberian makanan yang terlalu awal atau terlambat, makanan yang diberikan tidak sesuai porsi dan frekuensi yang kurang (Motsa, Ibisomi, \& Odimegwu, 2016). Pemberian makanan yang terlalu lambat akan menyebabkan bayi mengalami kesulitan mengunyah, tidak menyukai makanan padat dan kekurangan gizi. Berdasarkan SDKI 2012 menunjukan bahwa 71,5 \% anak usia 6-24 bulan mendapatkan makanan dari sayuran dan buah yang kaya vitamin A dan sebesar 37 persen diberi makan sesuai dengan semua praktik IYCF (infant and young child feeding practice) yang direkomendasikan (produk susu atau susu, dengan keragaman yang memadai dan frekuensi makan). Hal ini menunjukan bahwa masih ada anak yang belum mendapatkan makanan yang kaya akan vitamin A dan pemberian MP-ASI yang belum sesuai standar WHO (Cooperative assistance and Relief Everywhere, 2010) 
Banyak hal yang telah dilakukan pemerintah dalam upaya peningkatan pemberian ASI eksklusif diantaranya adalah sarana pelayanan kesehatan mempunyai kebijakan Peningkatan Pemberian Air Susu Ibu (PP-ASI) tertulis yang secara rutin dikomunikasikan kepada semua petugas, melakukan pelatihan bagi petugas dalam hal pengetahuan dan keterampilan untuk menerapkan kebijakan tersebut, menjelaskan kepada semua ibu hamil tentang manfaat menyusui dan penatalaksanaannya dimulai sejak masa kehamilan, masa bayi lahir sampai umur 2 tahun termasuk cara mengatasi kesulitan menyusui, membantu ibu mulai menyusui bayinya dalam 30 menit setelah melahirkan yang dilakukan di ruang bersalin (inisiasi dini)

Menurut UNICEF dan WHO pada 6 bulan pertama bayi harus diberikan ASI eksklusif dan setelah 6 bulan keatas bayi dapat diberikan ASI dan makanan pendamping ASI sampai anak berumur minimal 2 tahun. Karena pada masa bayi 6 bulan keatas ASI sudah tidak mencukupi kebutuhan nutrisi pada bayi sehingga memerlukan MP-ASI yang berfungsi sebagai proses belajar mencerna makanan. MP-ASI yang baik memiliki beberapa kriteria yaitu tinggi protein dan energi, memiliki nilai suplementasi yang baik serta mengandung vitamin dan mineral yang sesuai, dapat dicerna, harganya ekonomis, bersifat padat gizi, dan memiliki perbandingan bentuk padat yang sedikit. Secara teoritis, pola pemberian MP-ASI dipengaruhi oleh faktor ibu, karena ibu yang mengatur segala nutrisi pada anak yang berpengaruh terhadap status gizi anak. Hal yang mempengaruhi pemberian MP-ASI diantaranya yaitu pengetahuan ibu tentang gizi, pendidikan ibu, tingkat pendapatan keluarga, pekerjaan ibu, adat istiadat dan penyakit infeksi Tingkat pendidikan formal ibu berperan penting dalam pembentukan pola pemberian MP-ASI pada bayi,semakin tinggi tingkat pendidikan ibu maka semakin mudah untuk memahami informasi mengenai MP-ASI, gizi, dan kesehatan yang pada akhirnya bisa mempengaruhi ibu dalam pemberian MP-ASI bayi yang akan berdampak pada baik atau buruknya status gizi bayi (Kristianto \& Sulistyarini, 2013; Nurlaila et al., 2018)

Berdasarkan hasil studi pendahuluan di desa Karanganyar terdapat 8 posyandu balita dan jumlah kader kesehatan balita sebanyak 50 orang. Hasil wawancara dengan ketua kader kesehatan balita di desa Karanganyar pada bulan November 2017 terdapat ibu hamil sebanyak 22 orang dan jumlah bayi usia 0-12 bulan sebanyak 56 bayi. Meskipun program posyandu di desa Karanganyar telah berjalan secara aktif, namun dalam pemanfaatan promosi ASI Eksklusif dan pemberian MP-ASI untuk bayi dari 0-12 bulan masih kurang. Pada kegiatan posyandu tersebut mereka hanya membahas masalah masalah yang lebih kompleks, jarang sekali membahas dalam pentingnya pemberian ASI Eksklusif dan pemberian MP-ASI untuk bayi usia 0-12 bulan. Salah satu kader Balita Desa Karanganyar menyampaikan belum pernah ada pendidikan kesehatan dan pelatihan tentang pemberian ASI Eksklusif dan MP ASI bagi warganya.

\section{BAHAN DAN METODE}

Tahapan dalam kegiatan ini adalah pemilihan kader, pelatihan kader PARAPAM, Pendampingan kader dan evaluasi. Pemilihan kader dilakukan penulis bersama dengan bidan desa serta ketua kader Desa Karanganyar. Pelatihan kader dilakukan selama 3 hari yang terdiri dari 1 hari pemaparan materi dan hari praktek pendampingan. Metode yang digunakan dalam pelatihan kader meliputi Ceramah, Diskusi, tanya jawab, dan Demonstrasi. Jumlah kader yang dilatih menjadi kader PARAPAM sebanyak 31 orang dari 6 RW di Desa Karanganyar. 
Data dikumpulkan melalui pembagian kuesioner pengetahuan kader sebelum dan sesudah pelatihan, serta lembar observasi untuk mengevaluasi kemampuan kader dalam memberikan edukasi serta pendampingan kepada ibu hamil dan menyusui. Media yang digunakan oleh kader PARAPAM dalam memberikan edukasi kepada masyarakat berupa booklet berjudul pemberian makan pada bayi dan anak, lembar balik serta leaflet. Data yang terkumpul dianalisis berdasarkan distribusi frekuensi.

\section{HASIL}

Kegiatan pengabdian masyarakat ini diikuti oleh 31 kader yang berjenis kelamin perempuan dan rentang usia 35 tahun sampai 56 tahun. Materi yang diberikan saat pelatihan kader meliputi pendidikan kesehatan, ASI Eksklusif dan MP-ASI.

\section{Tabel 1.}

Distribusi Frekuensi Pengetahuan kader PARAPAM sebelum dan setelah Pelatihan

\begin{tabular}{ll}
\hline \multicolumn{1}{c}{ Pengetahuan } & \multicolumn{1}{c}{ Pengetahuan } \\
Sebelum Pelatihan & Setelah Pelatihan \\
\hline Rata-rata $=61,5$ & Rata-rata $=74,5$ \\
Tertinggi $=69$ & Tertinggi $=85$ \\
Terendah $=42$ & Terendah $=56$ \\
\hline
\end{tabular}

Pada tabel 1 menunjukan bahwa terdapat peningkatan pengetahuan kader tentang ASI eksklusif dan MP-ASI setelah pelatihan kader PARAPAM. Hasil observasi terhadap kemampuan kader PARAPAM dalam memberikan edukasi dan pendampingan menunjukan bahwa semua kader memiliki kemampuan yang baik yaitu sebanyak 29 kader $(93,6 \%)$ dan kemampuan sangat baik sebanyak 2 orang $(6,4 \%)$.

Kader PARAPAM melakukan kunjungan kepada ibu menyusui dan ibu yang sedang memberikan MP-ASI pada anaknya pada masing-masing RW setiap bulan. Kader melakukan observasi langsung terhadap perilaku ibu dalam pemberian ASI dan MP-ASI serta memberikan dukungan positif kepada masyarakat. Hasil observasi penulis kepada 6 orang ibu menyusui pada 3 bulan setelah pelatihan, menunjukan bahwa 2 orang ibu memberikan ASI Eksklusif kepada bayinya serta 4 orang ibu memberikan MP-ASI sesuai standar WHO kepada anaknya. Para ibu menyampaikan bahwa keberadaan kader PARAPAM membantu proses menyusui dan pemberian makan pada anak.

\section{PEMBAHASAN}

Hasil kegiatan ini menunjukan terbentuknya 31 orang kader PARAPAM di 6 RW Desa Karanganyar. Berjenis kelamin semua perempuan dan usia antara 35 tahun - 56 tahun. Pada usia ini seseorang sudah terbentuk kematangan serta memiliki pengalaman dalam perawatan bayi dan anak. Kondisi ini mendukung peran kader dalam memberikan edukasi dan pendampingan kepada masyarakat. Hal ini sesuai dengan penelitian Wirapuspita, (2013) yang menunjukan bahwa umur berpengaruh terhadap minat menjadi kader posyandu yaitu terutama antara umur 30-40 tahun. 
Peningkatan tingkat pengetahuan kader PARAPAM sebelum dan setelah pelatihan dapat mendukung keberhasilan dalam proses menyusui dan perilaku pemberian MP-ASI pada anak. Kader yang memiliki pengetahuan yang baik mampu memberikan informasi kepada masyarakat dengan baik pula. Kader kesehatan dengan pengetahuan tinggi memiliki kemungkinan untuk aktif 18 kali lebih besar daripada pengetahuan rendah. Kader kesehatan dengan sikap baik memiliki kemungkinan untuk aktif 8 kali lebih besar daripada sikap kurang. Kader kesehatan dengan motivasi tinggi memiliki kemungkinan untuk aktif 15 kali lebih besar daripada motivasi rendah (Wijaya, 2013). Kader yang memiliki pengetahuan yang cukup akan lebih percaya diri dalam memberikan edukasi kepada masyarakat. Hal ini sejalan dengan penelitian Wirapuspita, (2013) yang menyatakan bahwa terdapat hubungan pelatihan dengan kinerja kader.

Hasil observasi menunjukan bahwa sebagian besar kader PARAPAM mampu melakukan pendampingan pada ibu menyusui dalam pemberian ASI dan MP-ASI pada anaknya. Kader yang merupakan bagian dari anggota masyarakat memiliki peran yang besar dalam mendampingi masyarakat. Kedekatan secara geografis dan kekeluargaan mendukung kemudahan proses edukasi dan pendampingan. Hal ini menunjukan bahwa peran kader telah dilaksanakan dengan baik. Hal ini sesuai dengan hasil penelitian Setyoadi, Ahsan, \& Abidin (2013) bahwa peran kader kesehatan sebagai koordinator, penggerak masyarakat, promosi kesehatan, pertolongan dasar dan pendokumentasian sudah dilaksanakan dengan baik. Peran pendampingan kader yang telah dilaksanakan dengan baik dapat dipengaruhi oleh tingkat pengetahuan kader yang baik pula. Hal ini sesuai dengan hasil penelitian Wijaya, (2013) bahwa terdapat hubungan yang signifikan antara pengetahuan, sikap, dan motivasi dengan keaktifan kader kesehatan dalam pengendalian kasus tuberkulosis. Pendampingan rutin oleh kader PARAPAM akan memberikan kemudahan akses informasi kepada masyarakat dan meningkatkan motivasi ibu dalam perilaku menyusui dan pemberian MP-ASI. Hal ini sesuai dengan penelitian Setyoadi et al. (2013) bahwa ada hubungan yang signifikan peran kader dengan tingkat kualitas hidup lansia. Peran kader yang baik berpengaruh terhadap tingkat kualitas hidup lansia. Kader selalu memberikan dukungan positif dan memberikan edukasi kepada lansia.

\section{SIMPULAN}

Keberadaan kader PARAPAM dapat memberikan pendidikan kesehatan dan dukungan kepada masyarakat dalam menyusui dan pemberian makanan pendamping ASI. Informasi dan dukungan kader PARAPAM mampu meningkatkan pemberian ASI Eksklusif dan MP-ASI pada bayi.

\section{REFERENCES}

Cooperative for Asistance and Relief Everywhere, I. (CARE). (2010). Infant And Young Child

Feeding Practices: Collecting and Using Data: A Step-by-Step Guide. Boston: Center for

Global Healts and International Development, Boston University.

Kementerian Kesehatan Badan Penelitian dan Pengembangan Kesehatan. (2018). Hasil

Utama RISKESDAS 2018.

Kementrian Kesehatan Republik Indonesia. (2013). Survei Demografi dan Kesehatan Indonesia

2012. Retrieved from http://kesga.kemkes.go.id/images/pedoman/SDKI 2012-

Indonesia.pdf 
Kristianto, Y., \& Sulistyarini, T. (2013). Faktor yang Mempengaruhi Perilaku Ibu dalam Pemberian Makanan Pendamping ASI pada Bayi USia 6-36 Bulan. Jurnal STIKES, 6(1), 99-108.

Motsa, L. F., Ibisomi, L., \& Odimegwu, C. (2016). The Influence of Infant Feeding Practices on Infant Mortality in Southern Africa. Matern Child Health J, 20, 2130. https://doi.org/https://doi.org/10.1007/s10995-016-2033-x

Nurlaila, Utami, W., \& Cahyani, T. . (2018). Buku Ajar Keperawatan Anak (1st ed.). Yogyakarta: Leutikaprio.

Setyoadi, Ahsan, \& Abidin, A. Y. (2013). Hubungan peran kader kesehatan dengan tingkat kualitas hidup lanjut usia. Jurnal Ilmu Keperawatan, 1(2), 183-192.

Wijaya, I. made kusuma. (2013). Pengetahuan, Sikap, dan Motivasi terhadap keaktifan Kader dalam Pengendalian Tuberkulosis. Jurnal Kesehatan Masyarakat, 8(2), 137-144.

Wirapuspita, R. (2013). Insentif dan Kinerja Kader Posyandu. Jurnal Kesehatan Masyarakat, $9(1), 58-65$. 